\title{
Evaluation of Oats (Avena sativa) Varieties for Adaptability Performances and Their Nutritional Value in the Highland of Masha, South West Ethiopia
}

\author{
Gezahegn Mengistu ${ }^{1}{ }^{*}$, Dereje Tulu ${ }^{1}$, Melkam Aleme ${ }^{1}$, Ararsa Bogale ${ }^{1}$, Mulisa Faji ${ }^{2}$ \\ ${ }^{1}$ Teppi Agricultural Research Center, Teppi, Ethiopia \\ ${ }^{2}$ Holeta Agricultural Research Center, Holeta, Ethiopia
}

Email address:

gezemen19@gmail.com (G. Mengistu)

${ }^{*}$ Corresponding author

To cite this article:

Gezahegn Mengistu, Dereje Tulu, Melkam Aleme, Ararsa Bogale, Mulisa Faji. Evaluation of Oats (Avena sativa) Varieties for Adaptability Performances and Their Nutritional Value in the Highland of Masha, South West Ethiopia. International Journal of Animal Science and Technology. Vol. 5, No. 3, 2021, pp. 70-74. doi: 10.11648/j.ijast.20210503.13

Received: August 12, 2021; Accepted: August 25, 2021; Published: September 4, 2021

\begin{abstract}
In Ethiopia, feed is the major production inputs that affect the production and productivity of animal. In this regard, One of the possible option to alleviate feed shortage is introduction and utilization of improved forage crops for the given production system. The study was conducted on 11 oat varieties during 2017 and 2018 main cropping season at Masha highland of south-western Ethiopia to evaluate their adaptability and identify high dry matter yield and good nutritional quality producing oat varieties for highland agro-ecological areas of south-west Ethiopia. The experiment was conducted using randomized complete block design replicated three times. Data were taken for days to $50 \%$ flowering, plant height, leaf to stem ratio, dry matter yield, grain yield and their nutritional contents. The data were analyzed using the general linear model procedures of SAS and the least significance difference was used for mean separation. The result of the combined analysis indicated that most of the agronomic traits were significantly $(\mathrm{p}<0.01)$ affected by varieties. The mean leaf to stem ratio of 79AB3849Tx) (80SA95) had the highest value (1.5) followed by PI-1706 (1.4). The tested oat varieties show significantly $(\mathrm{p}<0.01)$ different among varieties in their dry matter yield. Among the evaluated oat varieties, PI-1706 gave the highest dry matter yield (12.7 ton/ha) followed by 79AB3849Tx) (80SA9) $(12.0$ ton/ha) whereas Clintland60MN16016 gave the lowest (5.4 ton/ha) dry matter yield. The result of grain yield of these two varieties were consistent with dry matter yield. Based on the chemical compositions, PI-1706, KY7078394Canada and 79AB3849Tx) (80SA95) were the best varieties in their crude protein contents. Thus, from the results of the present study it can be concluded that PI-1706, 79AB3849Tx) (80SA95) and KY7078394Canada were best adapted and high yielder oat varieties and can be demonstrated on farm condition for wider use in the highlands of Bench-maji and Masha areas and in similar agro-ecological zones of south-western Ethiopia.
\end{abstract}

Keywords: Adaptability, Dry Matter Yield, Nutritional Value, Oat Variety, South-western Ethiopia

\section{Introduction}

Ethiopia has the largest livestock population in Africa [1] with estimated 57.83 million cattle, 28 million sheep, 28.6 million goat, 1.23 million camels, 60.5 million poultry, 2.1 million horses, 0.4 million mules and 7.88 million donkeys. However the production and productivity is low due to many factors among, feed is the major production inputs that affect the production and productivity of animal. In many parts of Ethiopia, animals are kept on poor quality natural pasture and crop residues [2]. However, the contribution of natural pasture was declining from time to time as a result of the expansion of crop production, poor management and seasonal availability [3, 4]. One of the possible option to alleviate feed shortage is introduction and utilization of improved forage crops for the given production system. Improved forage crops species are very important because of their high biomass yield and good nutritional value. 
In this regard, Oats (Avena sativa) is fast growing and the most widely used annual forage grass worldwide. It is highly palatable and an important energy rich and nutritious fodder for ruminant livestock [5]. Oat is well-adapted to a wide range of soil types from reddish brown to clay soil. The crop is a dual purpose feed -food crop grown in the high lands of Ethiopia under rain fed conditions [6, 7]. It is used as fodder crop (as green chops, ensilage, haying and grazing) and the palatability and its forage quality as good energy source for livestock. The oat grains make a good balanced concentrate in the ration for poultry, cattle, sheep and other animals [8].

Forage crops can be provided to animals directly through grazing pasture land, cut and carried feeding system or conserved for dry season use in mixes with crop residues and natural pasture hay [9]. The southwestern part of Ethiopia, particularly in the highlands of Sheka, Bench-sheko and South-west Omo administrative zones, improved forage species, best suited to the areas, are not well known, widely produced and utilized as animal feed. As indicated by [10] study feed shortage both in quantity and quality was the major problem constraining the livestock production and productivity in the south western Ethiopia. Therefore, it was very essential to evaluate and identify these improved oat varieties that are more adapted and well performed to the existing agro-ecological conditions to alleviate feed shortage both in quantity and quality and thus increase the production and productivity of livestock for both small scale and large scale producers. Hence the objectives of this study were to evaluate and identify high biomass yield and good nutritional quality producing oat varieties for highland areas of Sheka, Bench-sheko and south-west Omo areas.

\section{Materials and Methods}

\subsection{Description of the Study Site/Area}

The experiment was undertaken at Masha experimental sub-site in the 2016 and 2017 main cropping season. Masha is located at $7^{\circ} 44^{\prime} 00^{\prime \prime}-7^{\circ} 82^{\prime} 00^{\prime \prime} \mathrm{N}$ latitude and 35 $29^{\prime} 00^{\prime \prime}$ $35^{\circ} 66^{\prime} 00^{\prime \prime} \mathrm{E}$ longitude about $710 \mathrm{kms}$ south west of Addis Ababa at the elevation of 2223 meters above sea level [11]. The average annual temperature is $23^{\circ} \mathrm{C}$ with mean minimum and maximum of $15^{\circ} \mathrm{C}$ and $25^{\circ} \mathrm{C}$, respectively. The mean annual rainfall of the area is $1870 \mathrm{~mm}$ [12].

\subsection{Experimental Treatments and Design}

Eleven (11) oat varieties were brought from Holeta Agriculture Research Center and sowed during 2016 and 2017 main cropping season at Masha highlands of Gembeka experimental sub-site. The experimental treatments (varieties) evaluated were CI-8237, PI-1569, PI-1801, CI-8235, Clintland60MN16016, Lampton, 79ab382TX (805A90), 79Ab3849Tx (80SA95), PI-1706, KY7078394Canada and SRCPX80Ab2764. The experiment was layout in randomized complete block design with plot size of $1.8 \mathrm{~m} \mathrm{x} 3$ $\mathrm{m}$ and replicated three times in six rows with $30 \mathrm{~cm}$ row spacing. Sowing was done by drilling at a rate of $100 \mathrm{~kg} \mathrm{ha}^{-1}$.
The spacing between plots and blocks were $1 \& 1.5 \mathrm{~m}$, respectively.

\subsection{Data Collection and Laboratory Analysis}

Agronomic data such as emergence date at eight week plot soil cover, days to $50 \%$ flowering, disease and pest incidence, plant height, leaf to stem ratio, dry matter yield and grain yield were considered. Plant height was measured from five plants and their mean was recorded. A total of four central rows used to estimate dry matter and seed yield. Fresh herbage was harvested at 50\% flowering stage from the left sides of central rows of each plot and weighted using spring balance to determine total fresh weight. From the fresh biomass 300 grams from each treatments were taken and separated into stem and leaf parts, and dried in oven at $65^{\circ} \mathrm{C}$ for 72 hours to determine the dry matter yield. Nutritional qualities of oat varieties was were analyzed for dry matter (DM), crud protein (CP), ash, neutral detergent fiber (NDF), acid detergent fiber (ADF) and acid detergent lignin (ADL). Ash and CP were analyzed, according to AOAC [13] procedures, igniting the samples with muffle furnance at $550^{\circ} \mathrm{C}$ and the $\mathrm{N}$ content was determined using kejeldhal procedures and multiplied by 6.25 to determine $\mathrm{CP}$ contents. The NDF, ADF and lignin contents were analyzed according to Van Soest [14]. The remaining two central rows used to determine seed yield.

\subsection{Statistical Analysis}

The data were analyzed using analysis of variance (ANOVA) in general linear models of SAS [15]. Mean differences among genotypes were separated with least significant difference $(L S D)$ at $(\mathrm{p} \leq 0.05)$ significant level. The statistical model used for analysis $\mathrm{Y}_{\mathrm{ijk}}=\mu+\mathrm{T}_{\mathrm{i}}+\mathrm{Y}_{\mathrm{j}}+(\mathrm{TY})_{\mathrm{ij}}+$ $+\mathrm{e}_{\mathrm{ijk}}$, Where: $\mathrm{Y}_{\mathrm{ijk}}=$ Response variables of varieties

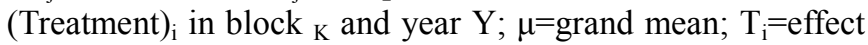
of treatments (varieties) I; $\mathrm{Y}_{\mathrm{j}}=$ year effect $\mathrm{J}$; $\mathrm{TY}_{\mathrm{ij}}$; treatment and year interaction; and $\mathrm{e}_{\mathrm{ijk}}=$ Random error.

\section{Result and Discussion}

\subsection{Year Interaction Effect}

The combined analysis of variance for yield and yield related traits of tested oat varieties over the two cropping years is presented in (Table 1). Cropping year had no significant effect $(\mathrm{P}>0.05)$ on most of the measured agronomic parameters. Except for grain yield year by variety interaction had no significant $(\mathrm{P}>0.05)$ effect on days to $50 \%$ flowering, plant height leaf to stem ratio and dry matter yield and this suggests an identical reaction to the environmental conditions. The result of this study indicated that the variations for measured traits were due to varietal difference than cropping season. Study done by Beyene et al. (2015) agreed that varieties has an effect on, plant height, dry matter yield and grain yield. The variation for the measured traits could be duet to difference in the genetic make of the oats genotypes. 
Table 1. Effect of variety and year on measured agronomic traits of oat varieties.

\begin{tabular}{|c|c|c|c|c|c|}
\hline \multirow{2}{*}{ Traits } & \multicolumn{2}{|c|}{ Mean square } & \multirow{2}{*}{ Variety *Year } & \multirow{2}{*}{ Mean } & \multirow{2}{*}{$\mathrm{CV}$} \\
\hline & Variety & Year & & & \\
\hline EWSC & $* * *$ & ns & Ns & 71.78 & 12.53 \\
\hline D50\% & $* * *$ & $\mathrm{~ns}$ & Ns & 96.27 & 6.21 \\
\hline PH (cm) & $* * *$ & ns & Ns & 149.46 & 6.29 \\
\hline LSR & $* * *$ & ns & Ns & 1.21 & 24.38 \\
\hline DMY (t/ha) & $* * *$ & $\mathrm{~ns}$ & Ns & 9.96 & 20.60 \\
\hline GY (qt/ha) & $* * *$ & $* *$ & $* *$ & 8.37 & 29.87 \\
\hline
\end{tabular}

\subsection{Plant Soil Cover, Days to Forage Harvest and Plant Height at Harvest}

The mean values of the tested oat varieties for eight week plant soil cover, days to forage harvest and plant height at harvest were showed in (Table 2). The combined means of oat varieties for plant soil cover percentage at eight week of emergency showed significant difference $(\mathrm{p}<0.001)$ among oat varieties. Accordingly, variety CI8237 scored the highest percentage for plot cover whereas Clintland60MN16016 showed statistically the lowest soil cover percentage. The difference might be due to seed size and seed viability of oat among varieties. Vigor is one of the important agronomic traits used to evaluate the establishment performance of forage crops. The differences in plant soil cover could be indicated differences in vigor on emergency and the size of endospore found in the seed among the genotypes. Study done by [16] suggested that vigor is one of the important agronomic traits used to evaluate the establishment performance of forage crops.

The overall means of tested oat varieties for days to forage harvesting had statistically significant $(\mathrm{P}<0.01)$ among varieties. Except PI-1706 variety, the rest of all the tested oat varieties had no statistically $(\mathrm{P}>0.05)$ difference for days to forage harvest. However, PI-1706 reached significantly late for days to forage harvest with mean value of 109.5 days. Significant difference for day to forage harvest or day to $50 \%$ flowering in oat genotypes have been reported by other authors $[16,17]$.

Table 2. Means of eight week plant soil cover, days 50\% flowering and plant height at harvest of the tested oat varieties at Gembeka experimental site across two years.

\begin{tabular}{|c|c|c|c|c|c|c|c|c|c|}
\hline \multirow{2}{*}{ Varieties } & \multicolumn{2}{|c|}{$\operatorname{EWSC}(\%) / \mathbf{M}^{2}$} & \multirow{2}{*}{ Mean } & \multicolumn{2}{|c|}{ D50\%F } & \multirow{2}{*}{ Mean } & \multicolumn{2}{|l|}{ PH (cm) } & \multirow{2}{*}{ Mean } \\
\hline & 2016 & 2017 & & 2016 & 2017 & & 2016 & 2017 & \\
\hline CI-8237 & $89.6^{\mathrm{a}}$ & $91.0^{\mathrm{a}}$ & $90.3^{\mathrm{a}}$ & $89.0^{c}$ & $89.6^{\mathrm{b}}$ & $89.6^{\mathrm{b}}$ & $180.4^{\mathrm{ab}}$ & $183.9^{\mathrm{ab}}$ & $182.2^{\mathrm{ab}}$ \\
\hline PI-1569 & $63.0^{\mathrm{cd}}$ & $67.0^{\mathrm{cd}}$ & $65.0^{\mathrm{cd}}$ & $89.2^{\mathrm{c}}$ & $93.7^{\mathrm{b}}$ & $93.7^{\mathrm{b}}$ & $127.5^{\mathrm{ef}}$ & $124.1^{\mathrm{g}}$ & $125.8^{\mathrm{fg}}$ \\
\hline CI-8235 & $53.7^{\text {ed }}$ & $57.7^{\mathrm{de}}$ & $55.7^{\mathrm{de}}$ & $95.0^{\mathrm{bc}}$ & $94.5^{\mathrm{b}}$ & $94.5^{\mathrm{b}}$ & $156.7^{\mathrm{cd}}$ & $154.3^{\mathrm{d}}$ & $155.5^{\mathrm{cd}}$ \\
\hline Clintland60MN16016 & $46.0^{\mathrm{e}}$ & $51.0^{\mathrm{e}}$ & $48.5^{\mathrm{e}}$ & $93.7^{\mathrm{bc}}$ & $96.3^{\mathrm{b}}$ & $96.3^{\mathrm{b}}$ & $140.4^{\text {cdef }}$ & $154.3^{\mathrm{d}}$ & $141.5^{\text {de }}$ \\
\hline Lampton & $87.3^{\mathrm{ab}}$ & $87.7^{\mathrm{ab}}$ & $87.5^{\mathrm{ab}}$ & $96.3^{\mathrm{bc}}$ & $98.2^{\mathrm{b}}$ & $98.2^{\mathrm{b}}$ & $120.5^{\mathrm{f}}$ & $123.1^{\mathrm{g}}$ & $121.8^{\mathrm{g}}$ \\
\hline 79AB3849Tx) (80SA95) & $78.6^{\mathrm{abc}}$ & $79.7^{\mathrm{abc}}$ & $79.2^{\mathrm{abc}}$ & $95.0^{\mathrm{bc}}$ & $98.2^{\mathrm{b}}$ & $98.2^{\mathrm{b}}$ & $167.7^{\mathrm{bc}}$ & $170.7^{\mathrm{bc}}$ & $169.2^{\mathrm{bc}}$ \\
\hline PI-1706 & $75.7^{\mathrm{abc}}$ & $76.7^{\mathrm{abc}}$ & $76.1^{\mathrm{abc}}$ & $107.3^{\mathrm{a}}$ & $109.5^{\mathrm{a}}$ & $109.5^{\mathrm{a}}$ & $188.9^{\mathrm{a}}$ & $190.3^{\mathrm{a}}$ & $189.6^{\mathrm{a}}$ \\
\hline KY7078394Canada & $72.7^{\mathrm{bc}}$ & $74.0^{\mathrm{b}} \mathrm{c}$ & $73.3^{\mathrm{bc}}$ & $97.2^{\mathrm{ab}}$ & $96.3^{\mathrm{b}}$ & $96.3^{\mathrm{b}}$ & $127.3^{\text {ef }}$ & $132.6^{\text {efg }}$ & $129.9^{\text {efg }}$ \\
\hline SRCPX80Ab2764 & $65.7^{\mathrm{cd}}$ & $65.3^{\text {cde }}$ & $65.0^{\mathrm{cd}}$ & $95.0^{\mathrm{bc}}$ & $94.2^{\mathrm{b}}$ & $94.2^{\mathrm{b}}$ & $136.2^{\mathrm{ef}}$ & $137.9^{\text {ef }}$ & $137.1^{\mathrm{ef}}$ \\
\hline $\mathrm{CV}$ & 13.1 & 11.3 & 13.4 & 4.7 & 5.3 & 5.3 & 6.8 & 5.6 & 6.1 \\
\hline LSD & 15.8 & 12.1 & 16.2 & 7.5 & 8.6 & 8.6 & 17.4 & 14.4 & 15.5 \\
\hline P Value & 0.003 & 0.007 & 0.004 & 0.006 & 0.01 & 0.01 & 0.001 & 0.001 & 0.001 \\
\hline $\mathrm{V}^{*} \mathrm{Y}$ & & & Ns & & ns & ns & & & ns \\
\hline
\end{tabular}

Means followed by different superscript letters within a column are significantly different each other at $\mathrm{P}<0.05$; EWSC-Eight week soil covers in percentage after germination; D50\%F-days to $50 \%$ of flowering; $\mathrm{PH}=$ plant height at harvest; $\mathrm{CV}=$ coefficient of variation; $\mathrm{NS}=$ non-significant at $(\mathrm{P}>0.05)$; $\mathrm{V} * \mathrm{Y}=\mathrm{variety}$ year interaction.

Table 3. Leaf to stem ratio, dry matter yield $\left(t \mathrm{ha}^{-1}\right)$, and seed yield (Qt ha $\mathrm{a}^{-1}$ ) of oat varieties evaluated at Gembeka experimental site across two years.

\begin{tabular}{|c|c|c|c|c|c|c|c|c|c|}
\hline \multirow{2}{*}{ Varieties } & \multicolumn{2}{|l|}{ LSR } & \multirow{2}{*}{ Mean } & \multicolumn{2}{|l|}{ DMY } & \multirow{2}{*}{ Mean } & \multicolumn{2}{|l|}{ GY } & \multirow{2}{*}{ Mean } \\
\hline & 2016 & 2017 & & 2016 & 2017 & & 2016 & 2017 & \\
\hline CI-8237 & 1.4 & 1.3 & $1.4^{\mathrm{ab}}$ & $9.6^{\mathrm{ab}}$ & $11.3^{\mathrm{ab}}$ & $10.4^{\mathrm{abc}}$ & $27.8^{\mathrm{bcd}}$ & $35.8^{\mathrm{a}}$ & $31.8^{\mathrm{ab}}$ \\
\hline PI-1569 & 1.2 & 0.9 & $1.0^{\mathrm{bcd}}$ & $9.8^{\mathrm{ab}}$ & $7.9^{\mathrm{de}}$ & $8.8^{\mathrm{c}}$ & $31.6^{\mathrm{abcd}}$ & $25.1^{\mathrm{fg}}$ & $28.3^{\mathrm{cd}}$ \\
\hline PI-1801 & 1.4 & 1.1 & $1.2^{\mathrm{abc}}$ & $11.7^{\mathrm{ab}}$ & $9.9^{\mathrm{bcd}}$ & $10.8^{\mathrm{abc}}$ & $28.7^{\text {bcd }}$ & $22.8^{\mathrm{g}}$ & $25.8^{\mathrm{d}}$ \\
\hline CI-8235 & 1.1 & 0.8 & $1.1^{\mathrm{bcd}}$ & $8.7^{\mathrm{bc}}$ & $8.7^{\mathrm{cd}}$ & $8.7^{\mathrm{c}}$ & $31.3^{\mathrm{abcd}}$ & $24.8^{\mathrm{fg}}$ & $28.1^{\mathrm{cd}}$ \\
\hline Clintland60MN16016 & 0.8 & 0.7 & $0.7^{\mathrm{d}}$ & $4.7^{\mathrm{c}}$ & $61.7^{\mathrm{e}}$ & $5.4^{\mathrm{d}}$ & $31.5^{\text {abcd }}$ & $35.8^{\mathrm{a}}$ & $33.7^{\mathrm{a}}$ \\
\hline Lampton & 1.3 & 1.1 & $1.3^{\mathrm{ab}}$ & $10.7^{\mathrm{ab}}$ & $12.0^{\mathrm{a}}$ & $11.3^{\mathrm{ab}}$ & $27.5^{\mathrm{cd}}$ & $23.8^{\mathrm{fg}}$ & $25.7^{\mathrm{d}}$ \\
\hline 79ab382TX (805A90) & 1.3 & 1.2 & $1.3^{\mathrm{ab}}$ & $9.5^{\mathrm{ab}}$ & $9.7^{\text {bed }}$ & $9.7^{\mathrm{bc}}$ & $32.8^{\mathrm{ab}}$ & $29.9^{\mathrm{cd}}$ & $31.4^{\mathrm{ab}}$ \\
\hline 79AB3849Tx) (80SA95) & 1.4 & 1.5 & $1.5^{\mathrm{a}}$ & $11.7^{\mathrm{ab}}$ & $12.3^{\mathrm{ab}}$ & $12.0^{\mathrm{ab}}$ & $32.5^{\mathrm{abc}}$ & $33.3^{\mathrm{ab}}$ & $32.9^{\mathrm{a}}$ \\
\hline PI-1706 & 1.5 & 1.4 & $1.4^{\mathrm{a}}$ & $13.1^{\mathrm{a}}$ & $12.4^{\mathrm{a}}$ & $12.7^{\mathrm{a}}$ & $31.9^{\text {abcd }}$ & $28.0^{\mathrm{de}}$ & $30.0^{\mathrm{bc}}$ \\
\hline
\end{tabular}




\begin{tabular}{|c|c|c|c|c|c|c|c|c|c|}
\hline \multirow{2}{*}{ Varieties } & \multicolumn{2}{|l|}{ LSR } & \multirow{2}{*}{ Mean } & \multicolumn{2}{|l|}{ DMY } & \multirow{2}{*}{ Mean } & \multicolumn{2}{|l|}{ GY } & \multirow{2}{*}{ Mean } \\
\hline & 2016 & 2017 & & 2016 & 2017 & & 2016 & 2017 & \\
\hline KY7078394Canada & 1.3 & 1.1 & $1.1^{\mathrm{abc}}$ & $11.4^{\mathrm{ab}}$ & $8.2^{\mathrm{de}}$ & $9.8^{\mathrm{bc}}$ & $36.2^{\mathrm{a}}$ & $31.7^{\mathrm{bc}}$ & $33.9^{\mathrm{a}}$ \\
\hline SRCPX80Ab2764 & 0.9 & 1 & $0.9^{\mathrm{cd}}$ & $8.2^{\mathrm{bc}}$ & $11.1^{\mathrm{abc}}$ & $9.6^{\mathrm{bc}}$ & $27.1^{\mathrm{d}}$ & $26.6^{\mathrm{ef}}$ & $26.8^{\mathrm{d}}$ \\
\hline $\mathrm{CV}$ & 22.3 & 26.7 & 24.3 & 25.3 & 14.1 & 20.6 & 9.7 & 5.8 & 8.3 \\
\hline LSD & 0.48 & & & 42.81 & 24.0 & 2.3 & 5.1 & 2.8 & 2.9 \\
\hline P Value & 0.07 & 0.12 & 0.001 & 0.04 & 0.002 & 0.001 & 0.03 & 0.001 & 0.001 \\
\hline $\mathrm{V} * \mathrm{Y}$ & & & Ns & & & Ns & & & \\
\hline
\end{tabular}

Means followed by different superscript letters within a column are significantly different each other at $\mathrm{P}<0.05$; LSR $=$ leaf to stem ratio; DMY=dry matter yield; GY=grain yield; $\mathrm{CV}=$ coefficient of variation; $\mathrm{NS}=$ non-significant at $(\mathrm{P}>0.05) ; \mathrm{V}^{*} \mathrm{Y}=$ variety year interaction.

Plant height has a positive effect on dry matter yield. The current study also showed that significant $(\mathrm{p}<0.001)$ differences for plant height at forage harvest among the oat varieties. The highest mean plant height was recorded for PI$1706(189.6 \mathrm{~cm})$ followed by $C I-8237(182.2 \mathrm{~cm})$ whereas variety PI-1706 was recorded the lowest mean $(121.8 \mathrm{~cm})$ plant height. The current study differences in plant height among varieties are expected due to the genetic variability. The present study in agreement with the report of [18] that significant differences among the oats varieties regarding plant height.

\subsection{Leaf to Stem Ratio, Dry Matter Yield and Grain Yield of Tested Oat Varieties}

The least squares means of tested oat genotypes for leaf to stem ratio, dry matter yield and grain yield were presented in (Table 3). The result of leaf to steam ratio showed numerical differences among varieties but statistically similar $(p>0.05)$ during the tested years. However the overall means of leaf to stem ratio showed significantly $(p<0.001)$ different among oat varieties and the highest leaf to stem ratio obtained for 79Ab3849Tx) (80SA95) and statistically similar with PI-1706 whereas the lowest scored for Clintland60MN16016. The dry matter yield $(\mathrm{t} / \mathrm{ha})$ for the tested oat varieties showed significant $(\mathrm{p}<0.001)$ difference among the oat varieties. Variety PI-1706 attained the highest dry matter yield (12.7 t $\mathrm{ha}^{-1}$ followed by 79AB3849Tx) (80SA95) and 79ab382TX (805A90) with statistical similar mean value of 12.0 and $11.3 \mathrm{t} \mathrm{ha} \mathrm{h}^{-1}$, respectively. Variety Clintland60MN16016 had the lowest dry matter yield (5.4 t/ha).

Grain yields of tested oat varieties showed significant difference $(\mathrm{p}<0.001)$ among varieties. The present study revealed that KY7078394Canada gave the highest grain yield 33.9 Quintal/ha whereas Lampton scored the lowest grain yield 25.7 Quintal/ha with statistically similar to PI-1801 (25.8 Quintal/ha).

\subsection{Chemical Composition of Oat Varieties}

The chemical composition (DM, Ash, CP, NDF, ADF and ADL) of evaluated oat varieties is indicated in (Table 4). The laboratory analysis indicated that the dry matter (DM) percentage ranges from 90.76 to 92.34 . Maximum crude protein content was obtained from PI-1706 whereas variety CI8237 had the lowest $\mathrm{CP}$ content. Based on the crude protein contents PI-1706, KY7078394Canada and 79AB3849Tx) (80SA95) were better oat varieties used for animal feeding.
Table 4. Chemical composition (\%) of tested oats varieties.

\begin{tabular}{lllllll}
\hline Varieties & DM & Ash & CP & NDF & ADF & ADL \\
\hline CI-8237 & 90.9 & 6.9 & 6.1 & 72.4 & 47.9 & 8.4 \\
PI-1569 & 92.3 & 8.5 & 7.7 & 67.8 & 44.7 & 6.5 \\
PI-1801 & 92.0 & 8.0 & 7.6 & 70.5 & 47.3 & 7.6 \\
CI-8235 & 92.1 & 7.8 & 6.4 & 70.1 & 48.6 & 6.1 \\
Clintland60MN16016 & 92.0 & 7.7 & 6.8 & 68.8 & 45.1 & 6.6 \\
Lampton & 91.0 & 8.8 & 8.4 & 69.2 & 44.4 & 8.8 \\
79ab382TX (805A90) & 90.8 & 8.3 & 6.8 & 68.4 & 44.9 & 7.1 \\
79AB3849Tx)(80SA95) & 91.0 & 8.4 & 8.3 & 70.4 & 45.8 & 8.9 \\
PI-1706 & 91.5 & 8.9 & 8.5 & 69.9 & 46.4 & 9.2 \\
KY7078394Canada & 92.4 & 8.6 & 8.1 & 70.9 & 49.6 & 8.5 \\
SRCPX80Ab2764 & 92.0 & 7.2 & 6.4 & 69.8 & 45.4 & 7.1 \\
\hline
\end{tabular}

\section{Conclusion}

The present result demonstrated that the tested oat varieties showed significant difference in most of the studied traits in the study area. Adaptability and productivity of the tested oat varieties, top three oat varieties were recommended to be very potential under Masha area and similar agro-ecology. In conclusion, Amongst the evaluated oat varieties, PI-1706 and 79AB3849Tx) (80SA95) and KY7078394Canada were the top three oat varieties recommended to be demonstrated on farmconditions and could play an important role in providing high dry matter yield, seed yield and with significant good nutritional quality. Therefore, livestock producers (both under smallholder farmers and semi-intensive livestock producers) could utilize as feed in cut and carry feeding system in highlands of Bench-maji, south west omo and Masha areas and similar agro-ecologies of south west Ethiopia.

\section{Acknowledgements}

The authors are highly acknowledged the Ethiopian Institute of Agricultural Research, forage research program in financial support for this work. The authors also would like to greatly acknowledged Holeta animal nutrition laboratory staffs for their assistance in laboratory analysis and Teppi Agricultural Research Center staffs for implementation and finalization of this study.

\section{References}

[1] CSA, 2016. Agricultural sample survey report on livestock and livestock characteristics, volume II, Addis Ababa, Ethiopia. 
[2] Tewodros M and Meseret M. 2013. Production Constraints, Farmers Preferences and Participatory on Farm Evaluation of Improved Forage Technologies in Selected Districts of Southern Ethiopia. Greener Journal of Agricultural Sciences. 3 (9), pp. 628-635.

[3] Alemayehu M. 2005. Rangelands: Biodiversity Conservation and Management and Inventory and Monitoring. Addis Ababa University, Faculty of Science, Addis Ababa, Ethiopia. Pp. 103.

[4] Feyisa T. and Dejen M. 2017. Assessment of major livestock feed resources and feeding systems in Bench-Maji zone; South Western part of Ethiopia. Online Journal in Animal Feed Research, 7 (6). pp. 145-153.

[5] Choudhary M. and Prabhu G. 2016. Response of fodder oat (Avena sativa L.) varieties to irrigation and fertilizer gradient.

[6] Kebede G. Feyissa F. Assefa G. Mengistu A. Tekletsadik T. Minta M. 2016. Study on current production and utilization status and further prospects of Oats (Avena sativa) in mixed farming systems of the central highland areas of Ethiopia. Acad. Res. J. Agri. Sci. Res. 4 (5): pp. 164-173.

[7] Demeke S, Asmare B, and Mekuriaw. 2017. Assessment of livestock production system and feed balance in watersheds of North Achefer district, Ethiopia. Journal of Agriculture and Environment for International Development - JAEID 2017, 111 (1): 175-190.

[8] Ayub, M., Shehzad, M., Nadeem, M. A., Pervez, M., Naeem. M., and Sarwar, N. (2011). Comparative Study on Forage Yield and Quality of Different Oat (Avena sativa L.) Varieties under Agro-Ecological Conditions of Faisalabad, Pakistan. African Journal Agriculture Research, 6, 3388-3391.

[9] Mengistu A. Kebede G, Assefa G, Feyissa F. 2016. Improved forage crops production strategies in Ethiopia: A review. Acad. Res. J. Agri. Sci. Res. 4 (6): pp. 285-296.
[10] Gezahegn, M., Endale, Y., Yadessa, Dereje, T., Melkam, A., Ararsa, B. and Kefene E., 2017. Survey on Livestock Production System Characterization in Bench-Maji, Sheka and Mejenger Zones, South Western Ethiopia. IJRAS, 4 (5): 231239.

[11] Kebede, B. 2002. Ethiopian Seasons classification. Retrieved from http://www. ethiopiantreasures.co.uk/pages/climate.htm.

[12] Benti, F. and Abara, M., 2019. Trend Analyses of Temperature and Rainfall and Their Response to Global $\mathrm{CO}_{2}$ Emission in Masha, Southern Ethiopia. Caraka Tani J. Sustain. Agric, 34, pp. 67-75.

[13] AOAC. 1990. Official Methods of Analysis, 15th ed. Assoc. Off. Anal. Chem., Washington, DC, USA.

[14] Van Soest PJ, JB Robertson, and BA Lewis. 1991. Methods for dietary fiber, neutral detergent fiber, and non-starch polysaccharides in relation to animal nutrition. Journal of Dairy Science, 74: 3583-3597.

[15] SAS, 2011. Statistical analysis system version 9.3, SAS Institute Inc., NC., USA.

[16] McCabe CP, Burke JI. 2021. Oat (Avena sativa) yield and grain fill responses to varying agronomic and weather factors. The Journal of Agricultural Science 1-16. https://doi.org/10.1017/ S0021859621000320.

[17] Mezgeb W. Yibra Y. Kidane G/meskel and Solomon M. 2019. Selection of Oats (Avena sativa) Accessions as Fodder Crop for Highland Environments. Proceedings of the 7th Annual National Review Workshop on Results of Livestock Research, May 2019, Holetta Research Center, Holetta.

[18] Beyene, G., Araya, A. and Gebremedhn, H., 2015. Evaluation of different oat varieties for fodder yield and yield related traits in Debre Berhan Area, Central Highlands of Ethiopia. Development, 27 (9). 